\title{
PENGEMBANGAN SILABUS, RPP DAN LKS MATERI GEOMETRI BERBASIS ETNOMATEMATIKA UNTUK MENINGKATKAN KARAKTER
}

\author{
Alfonsa Maria Abi ${ }^{1 \bowtie}$ dan Netty J. Marlin Gella ${ }^{2}$ \\ ${ }^{1,2}$ Prodi Pendidikan Matematika, STKIP Soe
}

\section{Info Artikel}

Sejarah Artikel:

Diterima 22 Apr

2019

Direvisi 22 Mei 2019

Disetujui $25 \mathrm{Mei}$

2019

\section{Keywords:}

ethnomathematic;

geometry; student work

sheet, lesson plan, silaby

\section{Paper type:}

Research paper

\section{Abstract}

This research is $R \&$ D with Borg \& Gall models using pre-experimental one group pretest-posttes design. Aiming to test the validity, practicality and effectiveness of the use of syllabus, lesson plans and worksheets developed. This research was conducted at Amanuban Barat Middle School 2 class VIII 2017/2018 school year on geometry material. The results of the study indicate that the syllabus, lesson plans and worksheets meet the criteria of valid, practical and effective. Its validity is $92.01 \%$ and its practicality of $91.13 \%$ is indicated by the positive response of students and teachers. The effectiveness of learning resources is seen from the significant differences in learning achievement between the experimental and control classes. Increasing learning achievement after implementation is 0.35 seen from the gain score. Implementation of the development of syllabus, RPP and LKS increases the character of students in the form of critical and active. Students are more critical and more active in visible learning when they solve problems.

Abstrak

Penelitian ini adalah Research and Development (R \& D) model Borg \& Gall menggunakan preexperimental one group pretest-posttest design. Bertujuan menguji kevalidan, kepraktisan dan keefektifan penggunaan silabus, RPP dan LKS yang dikembangkan. Penelitian ini dilakukan di SMP Negeri 2 Amanuban Barat kelas VIII tahun ajaran 2017/2018 pada materi geometri. Hasil penelitian menunjukkan bahwa silabus, RPP dan LKS memenuhi kriteria valid, praktis dan efektif. Kevalidannya sebesar $88,4 \%$ dan kepraktisannya sebesar $82,3 \%$ ditunjukkan dengan respon positif siswa dan guru. Keefektifan sumber belajar dilihat dari perbedaan prestasi belajar yang signifikan antara kelas eksperimen dan kontrol. Peningkatan prestasi belajar setelah implementasi sebesar 0,35 atau berkategori sedang dilihat dari skor gain. Implementasi pengembangan silabus, RPP dan LKS meningkatkan karakter siswa berupa kritis dan aktif. Siswa lebih kritis dan lebih aktif dalam pembelajaran terlihat ketika mereka menyelesaikan masalah.
\end{abstract}




\section{PENDAHULUAN}

Arus globalisasi dan berbagai masalah lingkungan hidup, kemajuan teknologi dan informasi, kebangkitan industri kreatif dan budaya, dan perkembangan pendidikan di tingkat internasional merupakan beberapa tantangan eksternal dari kurikulum 2013. Arus globalisasi akan menggeser pola hidup masyarakat dari agraris dan perniagaan tradisional menjadi masyarakat industri dan perdagangan modern (Permendikbud, 2014). Oleh karena itu, sekolah menjadi salah satu tonggak dalam rangka memberdayakan nilai-nilai karakter bangsa.

Pembentukan nilai karakter bangsa dirumuskan secara khusus dalam kompetensi sikap spiritual dan sosial meskipun kompetensi pengetahuan dan ketrampilan turut mendukung pengembangan kedua sikap tersebut yang harus dicapai dalam suatu pembelajaran. Matematika merupakan salah satu mata pelajaran wajib di sekolah mulai dari dasar sampai perguruan tinggi. Dengan demikian, matematika menjadi salah satu pilar dalam membentuk sikap, pengetahuan dan ketrampilan siswa dikarenakan karakteristik matematika sekolah yang adalah alat, pola pikir dan ilmu atau pengetahuan (Suherman, 2003).

Pencapaian tujuan pembelajaran matematika perlu direncanakan dengan baik oleh guru dengan memperhatikan lingkungan belajar siswa, kemampuan siswa, dan tingkat kesulitan materi yang sering digunakan dalam penentuan kriteria ketuntasan minimum (KKM). Semuanya dirumuskan dalam silabus, Rencana Pelaksanaan Pembelajaran (RPP) dan lembar kerja siswa (LKS) dengan tujuan agar membantu guru dalam menghantar siswa memperoleh pengalaman menggunakan matematika sebagai alat untuk memahami dan menyajikan suatu informasi. Selain itu, matematika mampu membentuk pola pikir dalam memahami suatu pengertian serta menalar atau menganalisis hubungan di antara pengertian itu.

Kebiasaan atau budaya siswa atau yang lebih dikenal sebagai etnomatematika dapat dipadukan dan dikembangkan penggunaannya dalam pembelajaran. D'Ambrosio menjelaskan etnomatematika sebagai matematika yang dipraktikan oleh kelompok budaya yang dapat diidentifikasi dalam jargon, kode, simbol, mitos, dan bahkan cara penalaran dan penyimpulan penalarannya spesifik (Francois, 2009). Banyak penelitian yang menjelaskan bahwa etnomatematika menjadi salah satu solusi untuk menjawab kebutuhan pembelajaran kontekstual. Terutama pada materi-materi matematika yang membutuhkan pendekatan sesuai dengan budaya siswa seperti geometri.

Geometri pada tingkat sekolah menengah pertama (SMP) lebih banyak menekankan pemahaman siswa pada pzengetahuan konsep berupa karakteristik bidang dan bangun serta bagaimana menghitung keliling dan luas bidang bangun tersebut. Sesuai dengan pendekatan saintifik yang menjadi ciri K13, pengetahuan konsep harus dipahami secara mendalam. Siswa haruslah menemukan makna dari apa yang dipelajarinya bukan hanya sekedar tahu. Hal ini sejalan dengan yang diungkapkan oleh Ausubel dalam teori belajar bermaknanya. Untuk itu, salah satu model pembelajaran yang mendukung capaian tersebut adalah project based learning (PjBL). Langkah-langkah model PjBL terdiri dari penentuan pertanyaan mendasar (esensial), desain perencanaan proyek, menyusun jadwal, memonitor kemajuan proyek, menguji proses dan hasil belajar serta melakukan evaluasi pengalaman membuat proyek atau pengalaman kegiatan belajar.

PjBL mendukung proses belajar bermakna yang melibatkan objek langsung dan tak langsung seperti yang diungkapkan oleh Gagne (Suherman, 2003). Objek langsung inilah yang mendasari dikembangkannya silabus, RPP dan LKS berbasis etnomatematika. Dengan pengembangan ini diharapkan masyarakat sekolah dan masyarakat pada umumnya menyadari pentingnya belajar matematika.

PjBL yang akan diterapkan pada pembelajaran di SMP Negeri 2 Amanuban Barat sebagai subjek penelitian dianggap perlu didasarkan pada hasil observasi. Dimana siswa sering belajar tanpa melibatkan objek-objek langsung yang bisa mereka manipulasi untuk melatih kemampuan berpikir kritis, kreatif dan kemampuan lainnya yang diharapkan dimiliki oleh siswa sebagai bagian dari tujuan pembelajaran matematika.

Keterlibatan objek-objek langsung yang dapat dimanipulasi dapat meningkatkan kompetensi pencapaian dalam pembelajaran. Hal ini sejalan dengan penelitian Ummu, Sri, dan Henry (2018) yang menyimpulkan bahwa kemampuan koneksi matematika siswa meningkat, rata-rata aktivitas belajar siswa dalam mengkoneksikan matematik siswa dengan diterapkannya model pembelajaran inkuiri berbantuan media manipulatif meningkat serta keterampilan guru dalam mengelola kegiatan pembelajaran matematika dengan media manipulatif juga meningkat. 
Abi (2016) juga menjelaskan bahwa kurikulum 2013 yang menanamkan pemikiran ilmiah dan pendidikan karakter, menjadi rasional untuk mengintegrasikan etnomatematika dan pembelajaran matematika. Hal ini didukung juga dengan hasil penelitian Matitaputty (2016) yang menjelaskan bahwa desain pembelajaran matematika dengan pendekatan etnomatematika dari suatu tradisi dan iteraksi sosial merupakan metode pembelajaran yang memberikan kontribusi kepada siswa untuk lebih tertarik belajar dan membawa pemahaman siswa untuk melihat hal yang berbeda dari biasanya.

Masalah dalam penelitian ini adalah bagaimana mengembangkan perangkat pembelajaran berupa silabus, RPP dan LKS untuk meningkatkan karakter peserta didik pada materi geometri khususnya prisma dan balok. Tujuan yang dicapai dalam penelitian ini adalah menguji hasil pengembangan berupa kevalidan, kepraktisan dan keefektifannya dalam pembelajaran dan menguji peningkatan karakter dalam pembelajaran.

\section{METODE PENELITIAN}

Desain penelitian ini adalah Research and Development menurut Borg and Gall yang meliputi penelitian dan pengumpulan data, perencanaan, pengembangan produk awal, uji coba produk awal / uji coba terbatas, penyempurnaan produk awal, uji coba lapangan lebih luas, penyempurnaan produk hasil uji lapangan lebih luas, uji coba produk akhir, revisi atau penyempurnaan produk akhir, diseminasi dan implementasi (Sugiyono, 2013). Pada tahap implementasi desain yang digunakan adalah preexperimental one group pretest-posttest design (Creswell, 2013).

Subjek penelitian ini adalah siswa SMP Negeri 2 Amanuban Barat kelas VIII tahun ajaran 2019/2020 pada materi geometri. Instrumen penelitian dan teknik pengumpulan data, berdasarkan tahap penelitian pengembangan Borg and Gall. Sedangkan teknik pengumpulan data menggunakan kuesioner atau sering disebut angket. Kuesioner atau angket sebagai alat pengumpul data adalah sejumlah pertanyaan tertulis, yang harus dijawab secara tertulis pula oleh responden (Hardari dan Martini, 2006: 120). Melalui penggunaan angket, data yang dibutuhkan dalam penelitian ini akan dikumpulkan.

\section{HASIL DAN PEMBAHASAN}

Etnomatematika dapat diintegrasikan dalam kurikulum pembelajaran matematika (Abi, 2105). Sesuai dengan latar belakang, bentuk etnomatematika suku Amanuban yang diangkat adalah oko yang berbentuk prisma segidelapan beraturan dan oko mama yang berbentuk balok. Karakteristik matematika yang terdapat pada kedua bentuk etnomatematika tersebut kemudian dianalisis keterkaitannya dengan kompetensi sesuai dengan pemetaan kurikulum 2013. Hasil analisis digunakan dalam pengembangan silabus, RPP dan LKS yang kemudian diuji kevalidan, kepraktisan dan keefektifan penggunaannya dalam meningkatkan karakter siswa tersebut untuk keaktifan dan kekritisan siswa.

Hasil uji validasi pada tabel 1 menunjukkan bahwa silabus, RPP dan LKS berkategori sangat valid dengan rata-rata presentase $88,4 \%$. Aspek-aspek pengembangan yang dinilai oleh validator berupa sistematika penyusunan, urutan kerja, kebenaran konsep, keterkaitan bentuk etnomatematika dan konsep, bahasa yang digunakan, Penyusunan dilakukan secara sistematis dengan memperhatikan tampilan, penyajian contoh soal yang kontekstual, dan kejelasan petunjuk.

Tabel 1. Hasil Validasi

\begin{tabular}{lcccc}
\hline Validator & Silabus & RPP & LKS & Kategori \\
\hline $\begin{array}{l}\text { Dosen } \\
\text { ahli }\end{array}$ & 85,33 & 86 & 85 & Valid \\
\hline $\begin{array}{l}\text { Teman } \\
\text { sejawat }\end{array}$ & 95 & 96 & 85 & Valid \\
\hline Guru & 88 & 90 & 85 & Valid \\
\hline $\begin{array}{l}\text { Rata- } \\
\text { rata }\end{array}$ & 89,56 & 90,67 & 85 & Valid \\
\hline
\end{tabular}

Kevalidan silabus, RPP dan LKS dijadikan sebagai acuan pengujian skala kecil untuk mengetahui kepraktisan hasil pengembangan dan diperoleh respon positif baik dari siswa maupun guru dengan persentase 82,3 $\%$ pada kategori praktis. Siswa menjadi lebih senang ketika belajar dan menyelesaikan soal. Dikarenakan masalah-masalah yang disajikan kontekstual dengan kehidupan mereka serta mereka merasa diberi kesempatan yang lebih luas dalam menyampaikan pendapatnya ketika belajar. Petunjuk-petunjuk pada LKS menjadikan mereka lebih paham langkah-langkah penyelesaiannya. Keadaan seperti ini membantu guru karena siswa lebih aktif ketika proses pembelajaran berlangsung dan sikap kritis mereka menjadi lebih baik dalam menyelesaikan soal. Hal ini didukung dengan pemilihan dan penerapan model pembelajaran $\mathrm{PjBL}$ yang 
mengharuskan siswa untuk meningkatkan keaktifannya dan berpikir secara kritis dalam memahami masalah dan memilih alternatif penyelesaiannya.

Hasil validasi dan kepraktisan kemudian digunakan sebagai tolak ukur untuk pengimplementasiannya dalam skala besar. Desain penelitian untuk uji skala besar adalah pre-experimental one group pretest-posttest design dengan kelas eksperimen diberlakukan pembelajaran berbasis etnomatematika menggunakan silabus, RPP dan LKS yang telah dikembangkan dan satu kelas kontrol tidak.

Uji $\mathrm{t}$ dua pihak terhadap hasil belajar siswa setelah implementasi diperoleh nilai thitung $=3,37 \geq$ ttabel $=1,697$ dengan $\alpha=0,05$. Ini berarti terdapat perbedaan signifikan pada prestasi belajar antara kelas eksperimen dan kelas kontrol. Sedangkan besarnya peningkatan adalah 0,35 dilihat dari skor gain ternomalisasi berada pada kategori sedang. Ini berarti baik silabus, RPP dan LKS yang digunakan dalam pembelajaran mampu meningkatkan prestasi belajar meskipun masih dalam tingkatan sedang. Dengan demikian, dapat dikatakan bahwa hasil pengembangan efektif meningkatkan prestasi belajar dikarenakan pada uji gain terdapat peningkatan prestasi belajar. Sedangkan pada uji t dua pihak diperoleh perbedaan signifikan antara nilai posttest dan pretest.

Saat implementasi dilakukan, banyak siswa yang kurang tanggap dan paham keterkaitan oko dan oko mama dengan konsep matematikanya. Maka dibutuhkan waktu yang lebih untuk menjelaskan terlebih dahulu keterkaitannya dengan matematika. Ini dikarenakan siswa belum terbiasa belajar menemukan. Siswa dibiasakan untuk menghafal rumus dan terkesan guru mendominasi kelas.

Siswa belum dibiasakan dengan langkahlangkah pembelajaran $\mathrm{PjBL}$ yang berupa menentukan pertanyaan mendasar (esensial), desain perencanaan proyek, menyusun jadwal, memonitor kemajuan proyek, menguji proses dan hasil belajar serta melakukan evaluasi pengalaman membuat proyek atau pengalaman kegiatan belajar dengan melibatkan etnomatematika atau benda-benda konkrit yang ada disekitar mereka. Siswa harus bisa belajar secara bermakna sesuai dengan teori belajar Ausubel.

Pengalaman belajar bermakna dan mendalam ini dapat membantu meningkatkan prestasi belajar siswa. Peningkatan ini berupa kemampuan komunikasi matematis dalam Kaselin, Sukestiyarno, dan Waluya (2013), meningkatnya kemampuan koneksi matematika siswa dan dalam Henry (2018) dan Rizka, Mastur, dan Rochmad (2014), serta meningkatnya kemampuan pemecahan masalah dalam Supriyanti, Mastur, dan Sugiman (2015). Meningkatnya kemampuan tersebut berimbas pada meningkatnya prestasi belajar.

Ketika prestasi belajar siswa meningkat, keaktifan dan kekritisan mereka ketika menyelesaikan masalah menjadi lebih baik. Siswa mampu menganalisis informasi dari petunjuk-petunjuk yang diberikan. Ini sejalan juga dengan hasil penelitian Supriyanti, Mastur, dan Sugiman (2015) yang menjelaskan bahwa selain kemampuan pemecahan masalahnya meningkat, rasa percaya diri siswa juga lebih baik. Siswa mulai memberanikan diri untuk bertanya baik kepada guru maupun teman dalam kelompok terkait kesulitan yang dialaminya tersebut. Ini artinya bahwa pembelajaran berbasis etnomatika juga mendukung pengembangan karakter siswa.

\section{SIMPULAN}

Hasil penelitian dan pembahasan menyimpulkan bahwa silabus, RPP dan LKS memenuhi kriteria valid, praktis dan efektif. Ini menjelaskan bahwa pengembangan berbasis etnomatematika layak digunakan dalam pembelajaran. Untuk mendapatkan hasil yang lebih baik terutama untuk meningkatkan karakter siswa dan juga meningkatkan prestasi belajar siswa maka perlu dilakukan pembiasaan belajar. Ketika siswa sudah terbiasa memahami dan mampu menyelesaikan masalah maka prestasi belajar mereka akan meningkat serta kesadaran mereka terhadap gambaran matematika yang abstrak akan mulai terkikis. Hal ini dapat membantu pembentukan karakter siswa seperti yang dirumuskan dalam kurikulum 2013.

Penelitian ini terlaksana berkat bantuan dari berbagai pihak. Untuk itu, diucapkan terima kasih kepada kemenristekdikti, keluarga besar SMP Negeri 2 Amanuban Barat, dan seluruh pihak yang dengan caranya masing-masing telah membantu terlaksananya penelitian ini.

\section{UCAPAN TERIMAKASIH}

Penulis mengucapkan terimakasih kepada segenap tim Pengelola Jurnal Anargya yang telah memberikan kesempatan kepada penulis untuk mempublikasikan karya ilmiahnya. 


\section{DAFTAR PUSTAKA}

Abi, A. M. 2016. Integrasi Etnomatematika dalam Kurikulum Matematika Sekolah. JPMI, I(1): 1-6.

Cresswell, W. J. 2013. Research Design Pendekatan Kualitatif, Kuantitaif dan Mixed Edisi Ketiga. Yogyakarta: Pustaka Belajar.

Francois, K. 2009. The Role Of Ethnomathematics Within Mathematics Education. Proceedings of CERME in Prancis in 2009, 1517-1526. Prancis.

Hardari, N dan Martini. 2006. Instrumen Penelitian Bidang Sosial. Yogyakarta: Gadjah Mada University Press.

Kaselin, Sukestiyarno, dan Budi W. 2013. Kemampuan Komunikasi Matematis Pada Pembelajaran Matematika Dengan Strategi REACT Berbasis Etnomatematika. UJMER, 2(2):121-127.

Matitaputty, C. 2016. Desain Pembelajaran Matematika Dengan Pendekatan Etnomatematika Pada Materi Nilai Tempat Kelas 2 Sekolah Dasar. LEMMA, III(1):1-12.

Rizka, S., Mastur, Z., dan Rochmad. 2014. Model Project Based Learning Bermuatan Etnomatematika Untuk Meningkatkan Kemampuan Koneksi Matematika. UJMER, 3(2):71-78.

Suherman, E., dkk. 2003. Strategi Pembelajaran Matematika Kontemporer. Bandung: UPI.

Supriyanti, Mastur Z., dan Sugiman. 2015. Keefektifan Model Pembelajaran Arias Berbasis Etnomatematika Terhadap Kemampuan Pemecahan Masalah Siswa Kelas VII. UJME 4 (2): 134-141.

Ummu, Z., Sri, U., dan Henry, S. B. 2018. Penerapan Model Inquiry Berbantuan Media Manipulatif Untuk Meningkatkan Kemampuan Koneksi Matematika Siswa SD. Anargya, 1(1):-.

Undang-Undang RI nomor 20 Tahun 2003 tentang Sistem Pendidikan Nasional.

Permendiknas RI Nomor 41 Tahun 2007 tentang Standar Proses untuk Satuan Pendidikan Dasar dan Menengah.

Permendikbud Nomor 22 Tahun 2016 tentang Standar Proses Pendidikan Dasar dan Menengah.

Permendikbud Nomor 58 Tahun 2014 tentang Kurikulum 2013 Sekolah Menengah Pertama/Madrasah Tsanawiyah. 